\title{
Short Communication: Casein Haplotype Variability in Sicilian Dairy Goat Breeds
}

\author{
I. Gigli, ${ }^{* 1}$ D. O. Maizon, ${ }^{*}$ V. Riggio, ${ }^{*}$ M. T. Sardina, ${ }^{*}$ and B. Portolano* \\ *Dipartimento Scienze Entomologiche, Fitopatologiche, Microbiologiche Agrarie e Zootecniche-Sezione Produzioni Animali, \\ Università degli Studi di Palermo, Viale delle Scienze-Parco d'Orleans, 90128 Palermo, Italy \\ †Instituto Nacional de Tecnología Agropecuaria, EEA Anguil, CC 11, 6326 La Pampa, Argentina
}

\section{ABSTRACT}

In the Mediterranean region, goat milk production is an important economic activity. In the present study, 4 casein genes were genotyped in 5 Sicilian goat breeds to 1) identify casein haplotypes present in the Argentata dell'Etna, Girgentana, Messinese, Derivata di Siria, and Maltese goat breeds; and 2) describe the structure of the Sicilian goat breeds based on casein haplotypes and allele frequencies. In a sample of 540 dairy goats, 67 different haplotypes with frequency $\geq 0.01$ and 27 with frequency $\geq 0.03$ were observed. The most common CSN1S1-CSN2-CSN1S2-CSN3 haplotype for Derivata di Siria and Maltese was FCFB (0.17 and 0.22, respectively), whereas for Argentata dell'Etna, Girgentana and Messinese was ACAB (0.06, 0.23, and 0.10, respectively). According to the haplotype reconstruction, Argentata dell'Etna, Girgentana, and Messinese breeds presented the most favorable haplotype for cheese production, because the casein concentration in milk of these breeds might be greater than that in Derivata di Siria and Maltese breeds. Based on a cluster analysis, the breeds formed 2 main groups: Derivata di Siria, and Maltese in one group, and Argentata dell'Etna and Messinese in the other; the Girgentana breed was between these groups but closer to the latter.

Key words: goat, casein haplotype, genetic polymorphism

In many areas of Europe such as the south of Italy, production of goat milk is an important economic resource. Argentata dell'Etna, Girgentana, Messinese, Derivata di Siria, and Maltese are the main goat breeds reared in Sicily. These 5 breeds represent autochthonous (Argentata dell'Etna, Girgentana, and Messinese) and cosmopolitan (Derivata di Siria and Maltese) valuable genetic resources for milk production as well as for local milk-derived products in Sicily. The genetic

Received January 31, 2008.

Accepted May 22, 2008.

${ }^{1}$ Corresponding author: igigli@unipa.it reservoir depends not only on the number of breeds but also on the genetic diversity among breeds (Crepaldi et al., 2001). Genetic studies in these breeds would help to add value and protect local genetic resources.

Polymorphisms of the 4 casein genes $\left(\mathrm{\alpha}_{\mathrm{S} 1}\right.$ : CSN1S1; 8: CSN2; $\alpha_{\mathrm{S} 2}$ : CSN1S2; and $\mathrm{x}$ : CSN3) have been the focus of considerable research effort because of their potential effects on milk composition. Polymorphism in CSN1S1 is associated with different concentrations of $\mathrm{a}_{\mathrm{S} 1}-\mathrm{CN}$ in milk. Alleles CSN1S1*A and CSN1S1*B are associated with high $a_{\mathrm{S1}^{-}} \mathrm{CN}$ concentration in milk; CSN1S1*E with an intermediate concentration; $C S N 1 S 1^{*} \mathrm{~F}$ with a low concentration; and finally $C S N 1 S 1{ }^{*} 0_{1}$ and $C S N 1 S 1 * \mathrm{~N}$ with the absence of $\mathrm{a}_{\mathrm{S} 1}-\mathrm{CN}$ in milk (Grosclaude and Martin, 1997). Polymorphism of CSN2 was found to be associated with a normal B-CN concentration in milk (alleles A, B, and C) or associated with no B-CN in milk (alleles 0 and 0'; Mahé and Grosclaude, 1993; Chessa et al., 2005). Allele CSN2*B was detected by isoelectrofocusing (IEF) and has not yet been characterized at the DNA level (Mahé and Grosclaude, 1993). Regarding CSN1S2, 7 different alleles have been reported in goat: A, B, C, D, E, F, and 0 (Ramunno et al., 2001a). These 7 alleles are associated with at least 3 levels of $\alpha_{\mathrm{S} 2}-\mathrm{CN}$ protein in milk: null (0 allele), intermediate (D allele), and normal (A, B, C, E, and F alleles; Ramunno et al., 2001a). For CSN3, which encodes a calcium-independent protein that plays a crucial role in casein micelles formation and stabilization, 16 alleles have been identified, corresponding to 13 protein variants (3 allele variations correspond to synonymous mutations; Prinzenberg et al., 2005).

Because the 4 casein genes are tightly linked on chromosome 6 (Ferretti et al., 1990; Threadgill and Womack, 1990), the downregulation of one casein gene might produce an upregulation of other casein genes (Hayes et al., 2006). Therefore, the study of casein haplotypes could provide more information than the study of individual casein genes. In this regard, Hayes et al. (2006) have shown that goat casein haplotypes have a large effect on milk production traits. In the present study, the 4 casein genes in 5 Sicilian goat breeds were 
Table 1. Alleles identified and methods used for genotyping casein

\begin{tabular}{|c|c|c|c|}
\hline Locus & Allele & Method $^{1}$ & Reference \\
\hline \multirow{2}{*}{ CSN1S1 } & $\mathrm{E}$, non-E & AS-PCR & Jansà Pérez et al. (1994) \\
\hline & $0_{1}$, non- $0_{1}$ & AS-PCR & Cosenza et al. (2003) \\
\hline \multirow[t]{3}{*}{ CSN1S2 } & $\mathrm{A}, \mathrm{B}, \mathrm{C}$, and $\mathrm{E}^{2}$ & IEF & Chiatti et al. (2007) \\
\hline & $\mathrm{A}, \mathrm{B}$, and $\mathrm{C}$ & AS-PCR & Parma et al. (1999) \\
\hline & $\mathrm{D}$ and 0 & PCR-RFLP & Ramunno et al. (2001a) \\
\hline
\end{tabular}

${ }^{1} \mathrm{AS}-\mathrm{PCR}$ = allele-specific-PCR; PCR-SSCP = PCR-single strand conformation polymorphism; IEF = isoelectrofocusing.

${ }^{2}$ When milk samples were available, CSN1S2 alleles A, B, C, and E were inferred from milk protein by IEF; otherwise, they were genotyped by AS-PCR.

${ }^{3} \mathrm{D} / \mathrm{I} / \mathrm{K} / \mathrm{L}$ were grouped as allele $\mathrm{D}$ in this work.

genotyped to identify casein haplotypes present in Argentata dell'Etna, Girgentana, Messinese, Derivata di Siria, and Maltese goat breeds, and to describe the structure of the Sicilian goat breeds based on casein haplotypes and allele frequencies.

Milk and blood samples were obtained from 540 goats belonging to 5 breeds (number of goats): Argentata dell'Etna (42), Girgentana (263), Messinese (49), Derivata di Siria (47), and Maltese (139). When possible, milk samples were collected and frozen until phenotyping by IEF. Blood samples were collected in EDTA Vacutainers (Becton Dickinson, Devon, UK) and preserved frozen until DNA extraction. The DNA was extracted from whole blood samples by glass silica membrane using GFX Genomic Blood DNA Purification Kit (Amersham Biosciences, Uppsala, Sweden), and the DNA samples were genotyped for CSN1S1, CSN2, CSN1S2, and CSN3. Table 1 shows detail of the methods. Amplifications were performed with GeneAmp PCR system 9700 (Applied Biosystems, Foster City, CA). The reaction mix consisted of $0.05 \mathrm{U} / \mu \mathrm{L}$ of Taq DNA polymerase, $4 \mathrm{mM} \mathrm{MgCl}, 0.4 \mathrm{~m} M$ each $\mathrm{dNTP}$ ( $2 \times$ PCR Master Mix, Fermentas, Vilnius, Lithuania), forward and reverse primer, $10 \mathrm{pmol}$ each, in a final volume of $20 \mu \mathrm{L}$.

The program GENEPOP version 3.4 (Raymond and Rousset, 1995) was used to obtain the allele frequencies and to test, by Fisher's method, deviations from Hardy-Weinberg equilibrium. The casein haplotypes were reconstructed within breeds using the PHASE program version 2.1 (Stephens et al., 2001; Stephens and Scheet, 2005) considering only alleles that had a frequency $\geq 5 \%$ in each breed. The software FSTAT (Goudet, 1995) was used to infer the gene diversity (Nei, 1973) and F-statistics (Wright, 1978; Weir and Cockerham, 1984) using casein genotypes. A cluster analysis was done with the CLUSTER procedure of SAS (SAS Institute, 2004), based on reconstructed haplotypes frequencies, using only haplotypes with a $3 \%$ or greater frequency within each breed.

Research on casein genetic polymorphisms has been motivated by its direct effect on milk characteristics. Table 2 shows CSN1S1, CSN2, CSN1S2, and CSN3 allelic frequencies. The greatest variation at the CSN1S1 locus was found in the Maltese breed. In this breed, frequencies observed are in agreement with those reported by Sacchi et al. (2005), except that these authors have not reported allele $\mathrm{N}$ in this breed, and have reported a greater frequency for allele E. We identified CSN1S1*N at a very low frequency in Maltese as well as in Girgentana (0.011 and 0.040, respectively). Allele $C S N 1 S 1{ }^{*} \mathrm{E}$ was observed only in Maltese (0.004). Allele $C S N 2 * \mathrm{C}$ was the most prevalent in all Sicilian goat breeds, followed by $C S N 2^{*} \mathrm{~A}$. Chessa et al. (2005), in a study on CSN2 locus in Italian goat breeds, also found allele $\mathrm{C}$ as the most predominant allele. Alleles $C S N 1 S 2^{*} \mathrm{~A}$ and $C S N 1 S 2^{*} \mathrm{~F}$ were found at greater frequencies than the other alleles in all breeds. In Maltese goats, CSN1S2*A, CSN1S2*F, and CSN1S2* C were the most frequent alleles, in agreement with Sacchi et al. (2005). However, those authors reported the presence of $\operatorname{CSN} 1 S 2^{*} \mathrm{~B}$ in the Maltese breed, whereas this allele was observed only in Girgentana and Messinese in the current study. Contrary to Marletta et al. (2004), CSN1S2*D was observed in Argentata dell'Etna (0.012) and Girgentana (0.006) breeds. Allele CSN1S2*E was observed in all breeds except Girgentana. The CSN3 locus is the most polymorphic gene among all goat caseins with only few alleles displaying a high frequency (Prinzenberg et al., 2005). Girgentana and Maltese presented the greatest number of CSN3 alleles, whereas Messinese showed the lowest (only alleles A, B, and D were observed). Allele $C S N 3^{*} \mathrm{~B}$ was the most common allele identified in the 5 breeds. Until Prinzenberg et al. (2005) proposed a new international nomenclature, CSN3 alleles had received different names. In this paper, we followed the 
Table 2. Allele frequencies for CSN1S1, CSN2, CSN1S2, and CSN3 loci in 5 Sicilian goat breeds

\begin{tabular}{|c|c|c|c|c|c|c|c|}
\hline Locus & Allele & \multicolumn{5}{|c|}{ Breed $^{1}$} & $\mathrm{OAM}^{2}$ \\
\hline \multirow[t]{4}{*}{ CSN1S1 } & $\mathrm{A}$ & 0.254 & 0.351 & 0.242 & 0.303 & 0.249 & 0.437 \\
\hline & $\mathrm{E}$ & $-^{3}$ & - & - & - & 0.004 & 0.001 \\
\hline & $\mathrm{F}$ & 0.169 & 0.186 & 0.226 & 0.325 & 0.327 & 0.341 \\
\hline & $\mathrm{N}$ & - & 0.040 & - & - & 0.011 & 0.022 \\
\hline \multirow[t]{6}{*}{ CSN1S2 } & A & 0.265 & 0.535 & 0.369 & 0.246 & 0.153 & 0.547 \\
\hline & B & - & 0.023 & 0.031 & - & - & 0.014 \\
\hline & C & 0.124 & 0.055 & 0.099 & 0.186 & 0.130 & 0.124 \\
\hline & D & 0.012 & 0.006 & - & - & - & 0.004 \\
\hline & $\mathrm{E}$ & 0.060 & - & 0.031 & 0.012 & 0.038 & 0.018 \\
\hline & $\mathrm{F}$ & 0.223 & 0.101 & 0.170 & 0.254 & 0.382 & 0.287 \\
\hline \multirow{3}{*}{ CSN3 } & $\mathrm{D}$ & 0.104 & 0.083 & 0.106 & 0.116 & 0.115 & 0.141 \\
\hline & G & - & - & - & - & 0.008 & 0.002 \\
\hline & M & - & 0.002 & - & 0.011 & - & 0.002 \\
\hline
\end{tabular}

${ }^{1} \mathrm{AE}=$ Argentata dell'Etna; GI = Girgentana; ME = Messinese; DS = Derivata di Siria; and MA = Maltese.

${ }^{2} \mathrm{OAM}=$ overall average frequencies across sampled animals.

${ }^{3}$ Frequency equal to zero.

new international nomenclature. Therefore, the high frequency reported for $C S N 3^{*} \mathrm{D}$ (old nomenclature) in Maltese goats by Sacchi et al. (2005) is in agreement with results from the current study, in which $C S N 3^{*} \mathrm{~B}$ was the most frequent allele. Allele $C S N 3^{*} \mathrm{D}$, initially named by Jann et al. (2004), was indeed renamed as CSN3*B by Prinzenberg et al. (2005). Girgentana and Maltese were the most polymorphic breeds at this locus. Alleles $C S N 3^{*} \mathrm{~A}$ and $C S N 3^{*} \mathrm{~B}$ were previously reported as the most frequent in European, African, and Asian goat breeds (Prinzenberg et al., 2005). Our results in Sicilian goat breeds showed mainly CSN3*B at this locus.

All casein loci were in Hardy-Weinberg equilibrium except for CSN2 and CSN3 in Maltese, and CSN3 in Girgentana $(P<0.05)$. Within-breed gene diversities (Nei, 1973) were $0.638,0.451,0.608$, and 0.495 , and the interbreed gene diversities were 0.026, 0.017, 0.068, and 0.006 for CSN1S1, CSN2, CSN1S2, and CSN3, respectively. The latter, an absolute measure of gene differentiation, indicated a low degree of separation among these breeds. The overall coefficient of gene differentiation (GST; Nei, 1973) was 0.041, and the overall $\theta$ (Weir and Cockerham, 1984) was 0.081. These 2 values, estimators of Wright's $\mathrm{F}_{\mathrm{ST}}$, showed a low degree of differentiation in allele frequencies among these breeds as well. This result is in agreement with that of Iamartino et al. (2005) in southern Italian goat breeds, even though their work was based on microsatellite analysis.

Casein haplotypes have been used previously to study genetic variability among northern (Vallesana and Roccaverano) and southern Italian (Maltese, Garganic, and Jonica) goat breeds (Sacchi et al., 2005). Casein haplotype variability was studied among the 5 Sicilian goat breeds. The total number of haplotypes found for each breed was about 70, except for Argentata dell'Etna, in which 116 were found. In all breeds, 67 haplotypes were found with a haplotype frequency $\geq 0.01$ and 27 with a haplotype frequency $\geq 0.03$. The number of haplotypes found with a frequency $\geq 0.03$ varied across breeds (Table 3). The haplotype diversities were high for all breeds, ranging from 0.864 in Maltese to 0.958 in Argentata dell'Etna. These results showed a greater diversity than those for casein gene alleles because there was a greater number of haplotypes than number of gene alleles. However, the allelic richness, estimated with the software FSTAT, was slightly greater for haplotypes (range 4.9 to 6.0) than for gene alleles (range 3.0 to 6.0). A distance matrix based on similarity measures was estimated with a cluster analysis; first, second, and third principal components, of this matrix, explained 58,24 , and $11 \%$ of the total variability, respectively, and formed 2 main groups: Derivata di Siria and Maltese vs. Argentata dell'Etna and Messinese; Girgentana was in between these 


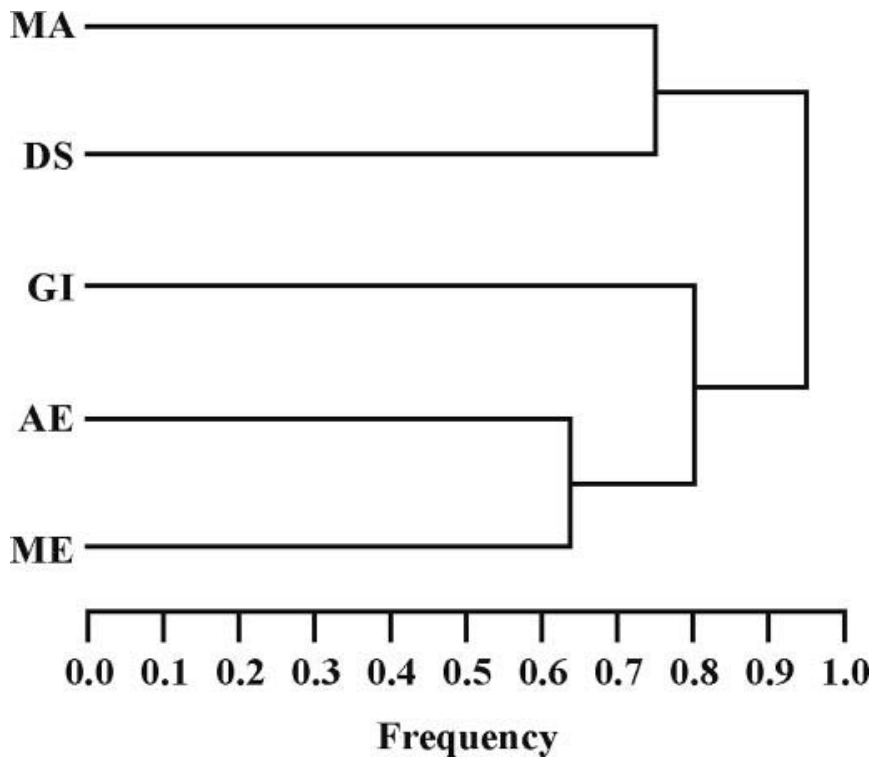

Figure 1. Clusters for casein haplotypes with frequency $\geq 0.03$ in 5 Sicilian goat breeds. AE = Argentata dell'Etna; GI = Girgentana; $\mathrm{ME}=$ Messinese $; \mathrm{DS}=$ Derivata di Siria; and MA = Maltese; scale shows distance between cluster centroids. groups (Figure 1). This result is in agreement with the origin of these breeds. Derivata di Siria and Maltese are cosmopolitan breeds, whereas Argentata dell'Etna, Messinese, and Girgentana are autochthonous breeds. Moreover, Argentata dell'Etna and Messinese were found to be, from a genetic viewpoint, very close to each other by Criscione et al. (2007).

Among the haplotypes with a frequency $\geq 0.03$, CSN1S1-CSN2-CSN1S2-CSN3 haplotypes A0'AB, BAAC, BCAC, and FCAA were only present in Girgentana; haplotypes A0'FB and FCFD in Maltese; haplotype ACFD in Derivata di Siria; haplotypes BACB and BCFB in Argentata dell'Etna; and haplotypes BCAA and FAFB in Messinese.

The most common haplotype for Derivata di Siria and Maltese was FCFB (0.17 and 0.22, respectively), and for Argentata dell'Etna, Girgentana, and Messinese was $\mathrm{ACAB}(0.06,0.23$, and 0.10 , respectively). This might indicate a very favorable combination for milk production, as CSN1S1*A is associated with a high level of $\mathrm{a}_{\mathrm{S} 1}$ - $\mathrm{CN}$ in milk (Grosclaude and Martin, 1997); $\mathrm{CSN}_{2}{ }^{*} \mathrm{C}$ and $\mathrm{CSN} 1 S 2^{*} \mathrm{~A}$ are indicative of normal B-CN (Neveu et al., 2002) and $\alpha_{\mathrm{S} 2}-\mathrm{CN}$ (Boulanger et al., 1984)

Table 3. Haplotypes of CSN1S1-CSN2-CSN1S2-CSN3 reconstructed within breeds and their frequencies (SE) in 5 Sicilian goat breeds (only haplotypes with frequency $\geq 0.03$ are presented)

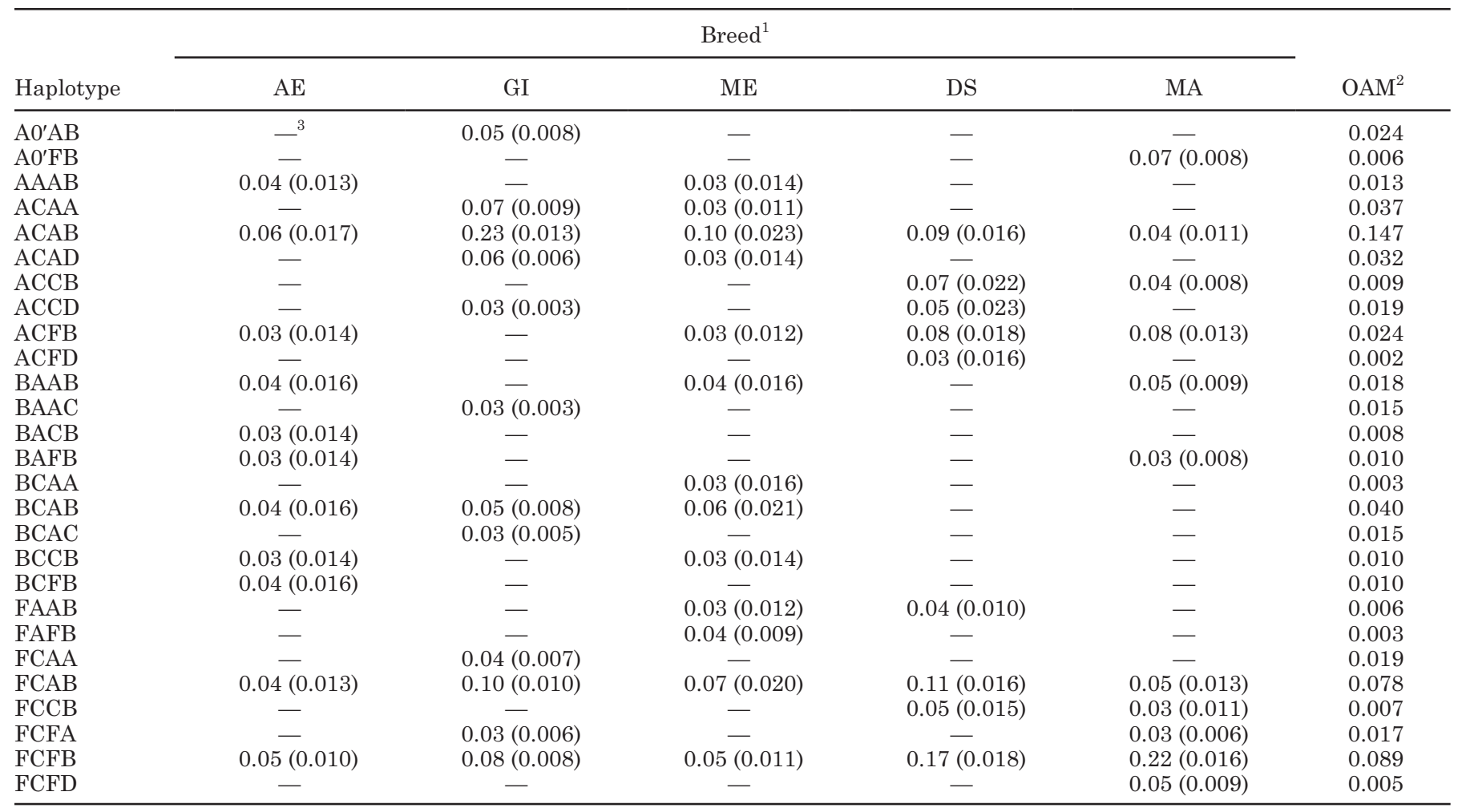

${ }^{1} \mathrm{AE}=$ Argentata dell'Etna $; \mathrm{GI}=$ Girgentana $; \mathrm{ME}=$ Messinese $; \mathrm{DS}=$ Derivata di Siria ; and MA = Maltese.

${ }^{2} \mathrm{OAM}=$ overall average frequencies across sampled animals.

${ }^{3}$ Frequency less than 0.03 . 
concentrations, respectively. In the Maltese breed, Sacchi et al. (2005) reported a casein haplotype similar to FCFB. These authors referred to haplotype FFD (CSN1S1, CSN1S2, and CSN3), which corresponds to FFB in the new nomenclature. Results from the current study, which were in agreement with those reported by Sacchi et al. (2005), also added the CSN2 locus in the Maltese casein haplotype construction.

In the Orobica breed, Caroli et al. (2006) found $C S N 3^{*} D$ only associated with $C S N 1 S 1{ }^{*} F$ and they concluded that this association might play a role in balancing protein expression. Subsequently, the association of the $\mathrm{B}^{\mathrm{IEF}}-\mathrm{CN}$ group $\left(C S N 3^{*} D / K / M\right)$ with a high percentage of $\mathrm{CN}$ and total proteins in goat milk was demonstrated in the same breed independently from the CSN1S1 genotype (Chiatti et al., 2007). At variance with Caroli et al. (2006), we not only found allele $C S N 3^{*} D$ to be associated with $C S N 1 S 1^{*} F$ in the Maltese, but also with allele $C S N 1 S 1^{*} A$ in Girgentana, Messinese, and Derivata di Siria. The association with $C S N 3^{*} D$ and $C S N 1 S 1$ alleles coding for a high content of the specific CN $\left(C S N 1 S 1^{*} A\right.$ and $\left.C S N 1 S 1^{*} B\right)$ was previously described in Garganica, Jonica, Maltese, and Roccaverano goats (Sacchi et al., 2005).

Haplotype information might be useful in a selection program because animals that carry casein haplotype $\mathrm{ACAB}$ could be superior for cheese production, whereas animals that carry FCAB could be superior for low casein milk production, and therefore for production of hypoallergenic goat milk. According to haplotype reconstruction, the Girgentana, Argentata dell'Etna, and Messinese breeds showed the most favorable haplotypes for cheese production, because casein protein concentration is expected to be greater in milk of these breeds compared with that from the Derivata di Siria and Maltese breeds.

\section{ACKNOWLEDGMENTS}

We wish to thank D. Calascibetta, G. D'Asaro, and G. Genco for their technical assistance. The first and second authors have been supported by a Marie Curie Transfer of Knowledge Grant of the European Community program "Quality of Life"; contract number MTKD/I-CT-2004-14412. The authors would also like to acknowledge the Ministero delle Politiche Agricole Alimentari e Forestali (MiPAAF) for financial support for this research (D.M. 302/7303/05).

\section{REFERENCES}

Boulanger, A., F. Grosclaude, and M. F. Mahé. 1984. Polymorphisme des caséines $\alpha_{\mathrm{S} 1}$ et $\alpha_{\mathrm{S} 2}$ de la chèvre (Capra hircus). Genet. Sel. Evol. 16:157-176.
Caroli, A., F. Chiatti, S. Chessa, D. Rignanese, P. Bolla, and G. Pagnacco. 2006. Focusing on the goat casein complex. J. Dairy Sci. 89:3178-3187.

Chessa, S., E. Budelli, F. Chiatti, A. M. Cito, P. Bolla, and A. Caroli. 2005. Short communication: Predominance of B-casein (CSN2) $\mathrm{C}$ allele in goat breeds reared in Italy. J. Dairy Sci. 88:18781881.

Chiatti, F., S. Chessa, P. Bolla, G. Cigalino, A. Caroli, and G. Pagnacco. 2007. Effect of $\mathrm{K}$-casein polymorphism on milk composition in the Orobica goat. J. Dairy Sci. 90:1962-1966.

Cosenza, G., R. Illario, A. Rando, P. Di Gregorio, P. Masina, and L. Ramunno. 2003. Molecular characterization of the goat CSN1S1(01) allele. J. Dairy Res. 70:237-240.

Crepaldi, P., R. Negrini, E. Milanesi, C. Gorni, M. Cicogna, and P. Ajmone-Marsan. 2001. Diversity in five goat populations of the Lombardy Alps: Comparison of estimates obtained from morphometric traits and molecular markers. J. Anim. Breed. Genet. 118:173-180.

Criscione, A., D. Marletta, T. Ådnøy, S. Bordonaro, A. M. Guastella, S. Lien, and G. D'Urso. 2007. Characterization of biodiversity in six goat breeds reared in Southern Italy by means of microsatellite and SNP markers. Ital. J. Anim. Sci. 6(Suppl. 1):95-97.

Ferretti, L., P. Leone, and V. Sgaramella. 1990. Long range restriction analysis of the bovine casein genes. Nucleic Acids Res. 18:68296833.

Goudet, J. 1995. FSTAT (Version 1.2): A computer program to calculate F-statistics. J. Hered. 86:485-486.

Grosclaude, F., and P. Martin. 1997. Casein polymorphisms in the goat. Pages 241-253 in Milk Protein Polymorphism. Int. Dairy Fed., Brussels, Belgium.

Hayes, B., N. Hagesæther, T. Ådnøy, G. Pellerud, P. R. Berg, and S. Lien. 2006. Effects on production traits of haplotypes among casein genes in Norwegian goats and evidence for a site of preferential recombination. Genetics 174:455-464.

Iamartino, D., A. Bruzzone, A. Lanza, M. Blasi, and F. Pilla. 2005. Genetic diversity of Southern Italian goat populations assessed by microsatellite markers. Small Rumin. Res. 57:249-255.

Jann, O. C., E. M. Prinzenberg, G. Luikart, A. Caroli, and G. Erhardt. 2004. High polymorphism in the $\mathrm{k}$-casein (CSN3) gene from wild and domestic caprine species revealed by DNA sequencing. J. Dairy Res. 71:188-195.

Jansà Pérez, M., C. Leroux, A. Sanchez Bonastre, and P. Martin. 1994. Occurrence of a LINE sequence in the $3^{\prime}$ UTR of the goat aS1-casein E-encoding allele associated with reduced protein synthesis level. Gene 147:179-187.

Mahé, M. F., and F. Grosclaude. 1993. Polymorphism of B-casein in the Creole goat of Guadeloupe: Evidence for a null allele. Genet. Sel. Evol. 25:403-408.

Marletta, D., S. Bordonaro, A. M. Guastella, and G. D’Urso. 2004. Genetic polymorphism at CSN1S2 locus in two endangered Sicilian goat breeds. J. Anim. Breed. Genet. 121:52-56.

Nei, M. 1973. Analysis of gene diversity in subdivided populations. Proc. Natl. Acad. Sci. USA 70:3321-3323.

Neveu, C., D. Mollé, J. Moreno, P. Martin, and J. Léonil. 2002. Heterogeneity of caprine beta-casein elucidated by RP-HPLC/ MS: Genetic variants and phosphorylations. J. Protein Chem. 21:557-567.

Parma, P., M. Feligini, L. Noè, R. Aleandri, S. Iametti, G. F. Greppi, and G. Enne. 1999. Detection of the goat a2-casein genetic variants by ASA-PCR. Anim. Genet. 30:231.

Prinzenberg, E. M., K. Gutscher, S. Chessa, A. Caroli, and G. Erhardt. 2005. Caprine k-casein (CSN3) polymorphism: New developments in molecular knowledge. J. Dairy Sci. 88:14901498.

Ramunno, L., G. Cosenza, M. Pappalardo, E. Longobardi, D. Gallo, N. Pastore, P. Di Gregorio, and A. Rando. 2001a. Characterization of two new alleles at the goat CSN1S2 locus. Anim. Genet. 32:264-268.

Ramunno, L., G. Cosenza, M. Pappalardo, N. Pastore, D. Gallo, P. Di Gregorio, and P. Masina. 2000. Identification of the goat 
CSN1S1F allele by means of PCR-RFLP method. Anim. Genet. 31:342-343.

Ramunno, L., E. Longobardi, M. Pappalardo, A. Rando, P. Di Gregorio, G. Cosenza, P. Mariani, N. Pastore, and P. Masina. 2001b. An allele associated with a non-detectable amount of $\alpha_{\mathrm{s} 2}$ casein in goat milk. Anim. Genet. 32:19-26.

Raymond, M., and F. Rousset. 1995. GENEPOP (version 1.2): Population genetics software for exact tests and ecumenicism. J. Hered. 86:248-249.

Sacchi, P., S. Chessa, E. Budelli, P. Bolla, G. Ceriotti, D. Soglia, R. Rasero, E. Cauvin, and A. Caroli. 2005. Casein haplotype structure in five Italian goat breeds. J. Dairy Sci. 88:15611568.

SAS Institute. 2004. SAS/STAT 9.1 User's Guide. SAS Inst. Inc., Cary, NC.
Stephens, M., and P. Scheet. 2005. Accounting for decay of linkage disequilibrium in haplotype inference and missing data imputation. Am. J. Hum. Genet. 76:449-462.

Stephens, M., N. J. Smith, and P. Donnelly. 2001. A new statistical method for haplotype reconstruction from population data. Am. J. Hum. Genet. 68:978-989.

Threadgill, D. W., and J. E. Womack. 1990. Genomic analysis of the major bovine milk protein genes. Nucleic Acids Res. 18:69356942.

Weir, B. S., and C. C. Cockerham. 1984. Estimating F-statistics for the analysis of population structure. Evolution 38:1358-1370.

Wright, S. 1978. Evolution and the Genetics of Populations. Vol. IV. Variability Within and Among Natural Populations. University of Chicago Press, Chicago, IL. 